\title{
Regionalization of congenital heart disease care: A pending goal
}

\section{La regionalización de la atención de cardiopatías congénitas: una meta pendiente}

\author{
Juan Calderón-Colmenero*
}

Department of Pediatric Cardiology, Instituto Nacional de Cardiología Ignacio Chávez, Mexico City, Mexico

\begin{abstract}
Congenital heart diseases (CHDs) are considered the most frequent malformations. In Mexico, every year between 12 and 16 thousand children are born with some type of $\mathrm{CHD}$ and it is the second cause of mortality in children under 1 year of age and in children aged between 1 and 4 years. The problem of the care of CHDs is analyzed from a perspective of health policies in the country with an emphasis on regionalizing their care to rationalize the use of available resources and with the aim of serving the largest number of patients and achieve the best clinical results. It emphasizes the need to promote cooperation among the different civil society organizations and institutions to exchange ideas to create consensus and joint projects for a better use of available resources to achieve universal and quality care of children with CHD in all the country.
\end{abstract}

Key words: Congenital heart disease. Heart surgery. Interventional catheterization. Child mortality. Health policies. Mexico.

\section{Resumen}

Las cardiopatías congénitas son consideradas las malformaciones más frecuentes. En México cada año entre 12 y 16 mil niños nacen con algún tipo de cardiopatía congénita, y es la segunda causa de mortalidad en menores de 1 año y en niños de entre 1 y 4 años. Se analiza la problemática de la atención de las cardiopatías congénitas desde una perspectiva de políticas de salud en el país, con énfasis en lograr regionalizar su atención con el fin de racionalizar la utilización de los recursos disponibles y con el objetivo de atender al mayor número de pacientes y lograr los mejores resultados clínicos. Se enfatiza la necesidad de promover la cooperación entre las diferentes organizaciones de la sociedad civil y las instituciones para intercambiar ideas que permitan crear consensos y proyectos conjuntos para una mejor utilización de los recursos disponibles para lograr la atención universal y de calidad de los niños con cardiopatía congénita en todo el país.

Palabras clave: Cardiopatías congénitas. Cirugía cardíaca. Cateterismo intervencionista. Mortalidad infantil. Políticas de salud. México.

\section{Correspondence:}

*Juan Calderón-Colmenero

Juan Badiano, 1

Col. Sección XVI, Del. Tlalpan

C.P. 14080 , Ciudad de México, México.

E-mail: juanecalderon@yahoo.com.mx
Date of reception: 24-09-2018

Date of acceptance: 22-02-2019

DOI: 10.24875/ACME.M19000036
Available online: $30-10-2019$ Arch Cardiol Mex (Eng). 2019;89(2):138-146 www.archivoscardiologia.com 2604-7063 @ 2019 Instituto Nacional de Cardiología Ignacio Chávez. Published by Permanyer México SA de CV. This is an open access article under the CC BY-NC-ND license (http://creativecommons.org/licenses/by-nc-nd/4.0/). 
"Poverty is a deprivation of certain capabilities, of which health is one, then by definition anything done to improve health reduces poverty."

Sir George Alleyne

There is no doubt that in Mexico there are advances in some social indicators: life expectancy went from around 36 years in 1910 to 75.3 years in 2017; mortality in infants < 1 year decreased from 37/1000 live births in 1990 to $12 / 1000$ live births in 2016; compliance with the vaccination program is $98 \%$, which is higher than in countries such as Italy, USA, and the United Kingdom.
Despite the listed achievements, our country is at a critical point in the field of health and it requires breaking with inertia, making a deep analysis of our problems and taking innovative actions (Fig. 1 and 2).

In the year 2000 , about $60 \%$ of the Mexican population had access to the Mexican Institute of Social Security (Instituto Mexicano del Seguro Social) or the Institute of Social Security and Services for State Workers (Instituto de Seguridad y Servicios Sociales de los Trabajadores del Estado); the Army, the Navy and Pemex (Petróleos Mexicanos - Mexican Oil Company) had

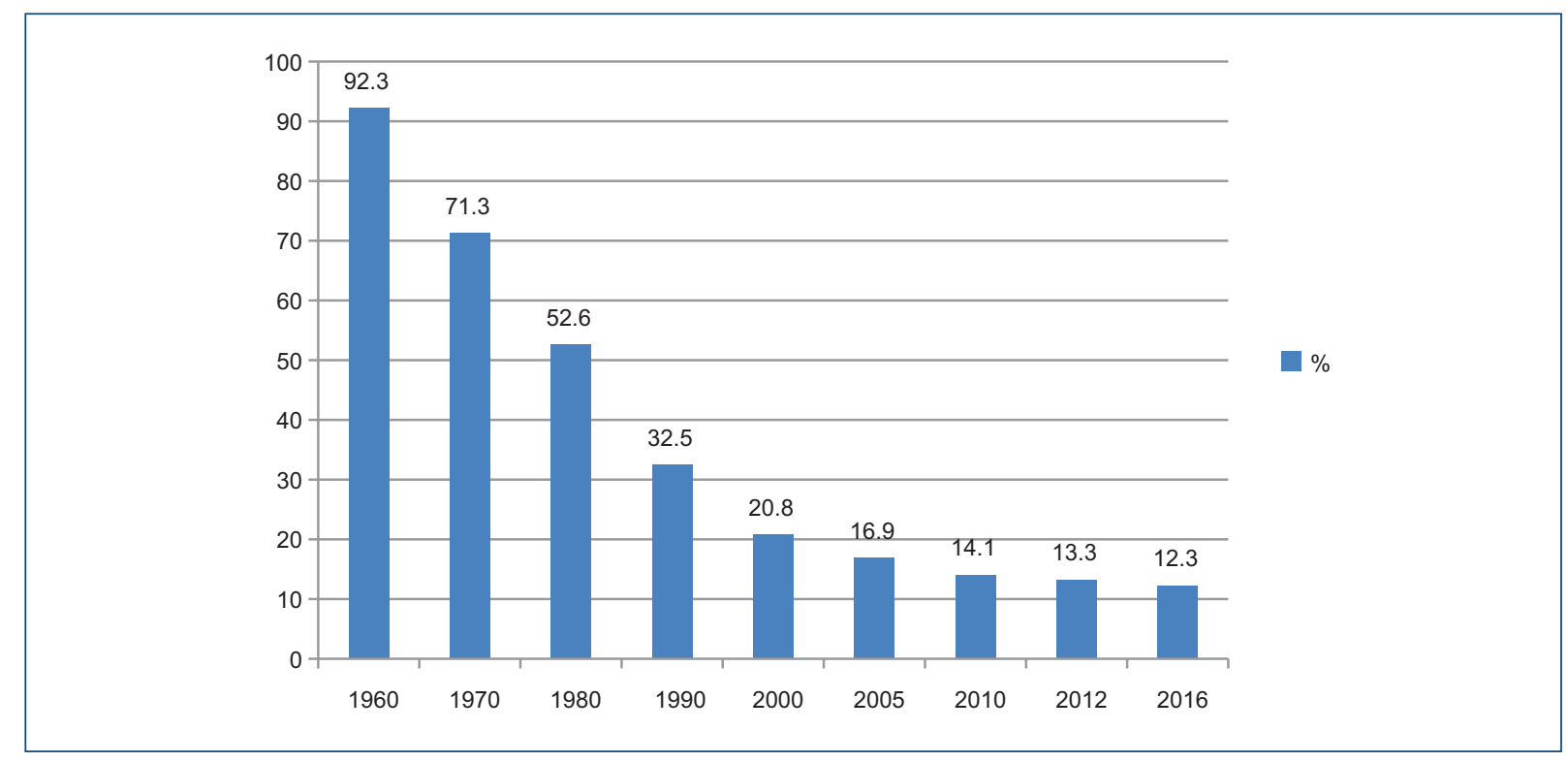

Figure 1. Mortality in children younger than 1 year (adapted from Organization for Economic Co-operation and Development [OECD]. MEXICO Country Highlights [OECD], doing better for children) ${ }^{13}$.

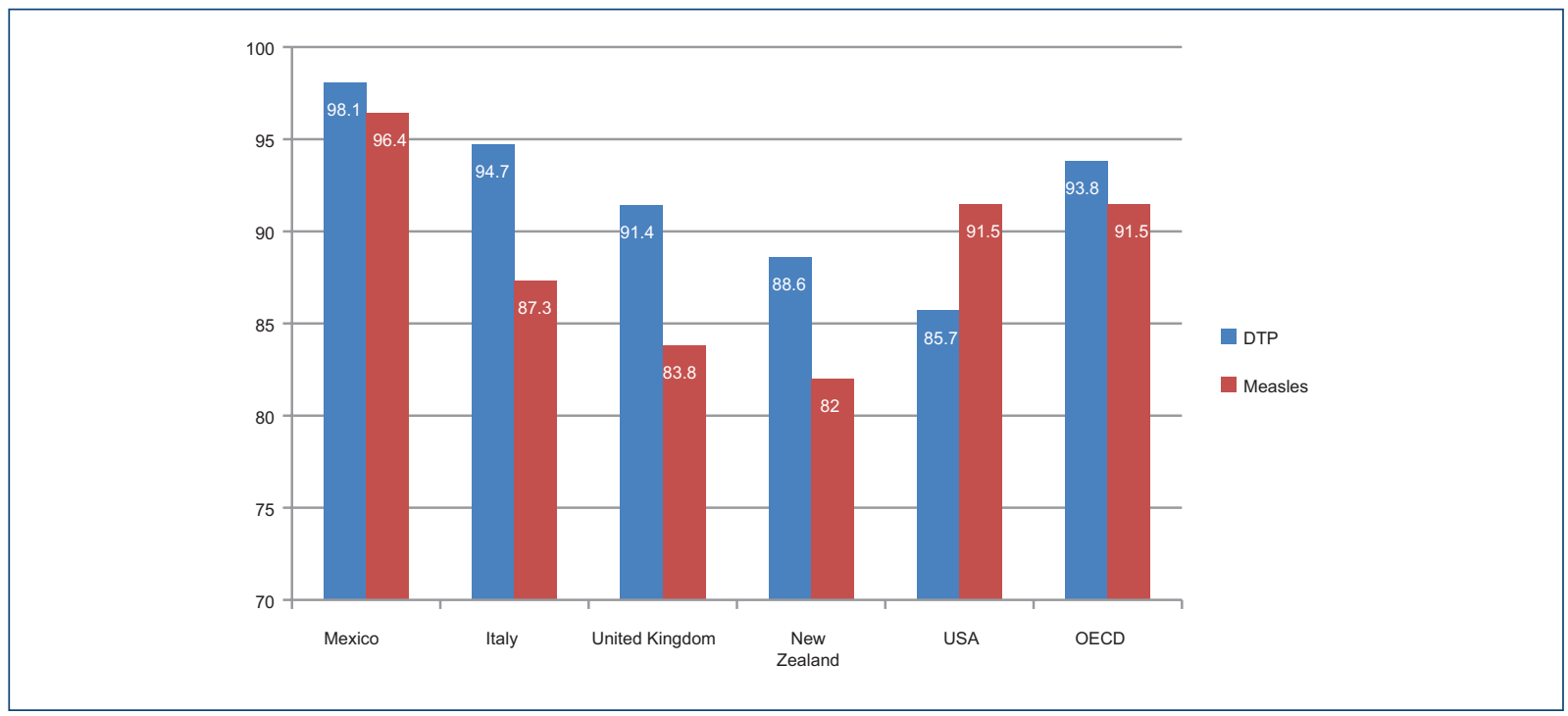

Figure 2. Percentage of vaccination compliance (adapted from IndexMundi) $)^{14}$.

DTP: diphtheria, tetanus, pertussis; OECD: Organization for Economic Co-operation and Development. 
their own health services; a small percentage had some type of private medical insurance $(<3 \%)$ and the rest of the population lacked any type of insurance for health services. Knaul et al. ${ }^{1}$ estimated that $63 \%$ of families, mostly poor and without social security, had to incur highly significant expenses, which had led to greater impoverishment. In addition, $58 \%$ of total health expenditure was estimated to come from households through out-of-pocket expenses. Mexico is the second country member of the Organization for Economic Cooperation and Development (OECD), after Latvia, with the highest percentage of out-of-pocket health expenses, defined as families' direct expenditure to meet health-care requirements, without including private medical insurance $^{2}$. According to information from the World Health Organization, investment in health in our country was $4.9 \%$ of the gross domestic product (GDP) in 2000 , it increased to $6.2 \%$ in 2009 and decreased to $5.9 \%$ in $2015^{3}$. Average health investment or health expenditure in Latin American countries is 7\%, whereas in the OECD countries it is $8.9 \%{ }^{4}$. On the other hand, Cano Valle et al. ${ }^{4}$ refer that, according to the OECD (2012), administrative expenditure in Mexico, which includes stewardship and management actions in the National Health System, is close to $10 \%$ of total public health expenditure, 2.5 times more than OECD countries' average, which is $4 \%$. This shows an insufficient investment in health, coupled with high and inefficient administrative expenditure ${ }^{5,6}$. This situation is not exclusive to our country: David Cutler, Applied Economics Professor at Harvard College, who is well known in the field of health, wrote in an essay that the resources invested in health services in the US that fail to generate an improvement in said services amount to $30 \%$ of total expenditure; according to Julio Frenk et al., this amount is equivalent to Mexican economy total value 7,8 .

Reports indicate that for every $10 \%$ increase in life expectancy, the GDP is increased by $4 \%{ }^{9}$. It is essential to establish a relationship between economic development and health and to modify paradigms to make for the focus of care to be a healthy population that can invigorate the economy and, as a consequence, in a harmonious circle, generating investment on well-being enhancement ${ }^{10}$. In our country, to increase the population covered by any type of medical insurance and to reduce families' out-of-pocket expenses, the Seguro Popular (People's Insurance) was created in 2003, which currently has 53 million affiliated people. This entity operates as an autonomous body of the Ministry of Health and has a service package known as Universal Catalog of Health Services (Catálogo Universal de interventions, in addition to, the Fund for Catastrophic Expenditure, which includes 149 high-cost interventions. According to figures from the Ministry of Health and the 2015 Inter-census Survey, the number of Mexicans with public health insurance went from nearly 40 million ( $41 \%$ of total population) to 98 million in $2015(82 \% \text { of total population })^{10-12}$. In the case of congenital heart malformations, the fund for catastrophic expenditure contemplates their care by means of surgery or interventional catheterization and, although it has had different regulations, in the last three 6-year periods, it has allowed these patients to be helped without medical care representing a significant out-of-pocket expense for households and financial devastation for health institutions. Based on actuarial calculations, the Seguro Popular makes a payment to the institution providing the service for each patient with congenital heart disease (CHD) who had a $\$ 100,743.00$ surgical or interventional procedure practiced. It would be convenient for the amount to be adjusted in relation to the complexity of the patients being treated based on the existing risk stratification methods: risk adjustment in congenital heart surgery-1, Aristotle, and Society of Thoracic Surgeons-European Association for Cardiothoracic Surgery (STS-EACTS); this correction would be of the utmost importance for those institutions that handle a higher volume of patients with more complex $\mathrm{CHD}^{15,16}$.

In 2010, we published the article "The problems of CHDs in Mexico. A proposal for Regionalization", where the problem was first approached from a country-wise perspective and regionalizing its approach was proposed to make better use of available resources, with the purpose to cover the largest number of patients and achieving the best clinical results ${ }^{17}$.

CHDs are considered the most common malformations and were defined by Mitchell et al. ${ }^{18}$ as "evident structural abnormalities of the heart or large intrathoracic vessels with real or potential repercussions." The referred CHD prevalence per 1000 live births ranges from 2.17 in Canada to 10.6 in Japan and 12.3 in Italy. These differences in prevalence can be explained by the timing of sampling, either in newborns or in children younger than 1 year of life; or by the fact that pathologies such as bivalve aorta, which is present in $1-2 \%$ of the population, or tiny ventricular septal defects, which have an incidence of $2-5 \%$ and have a spontaneous closure in up to $90 \%$ of children, and silent ductus arteriosus without hemodynamic repercussion, are included ${ }^{19,20}$.

Although we do not know the prevalence of $\mathrm{CHD}$ in Mexico, extrapolating from the reported global prevalence and knowing the number of annual births (around 2 million), it can be claimed that between 12 and 16 


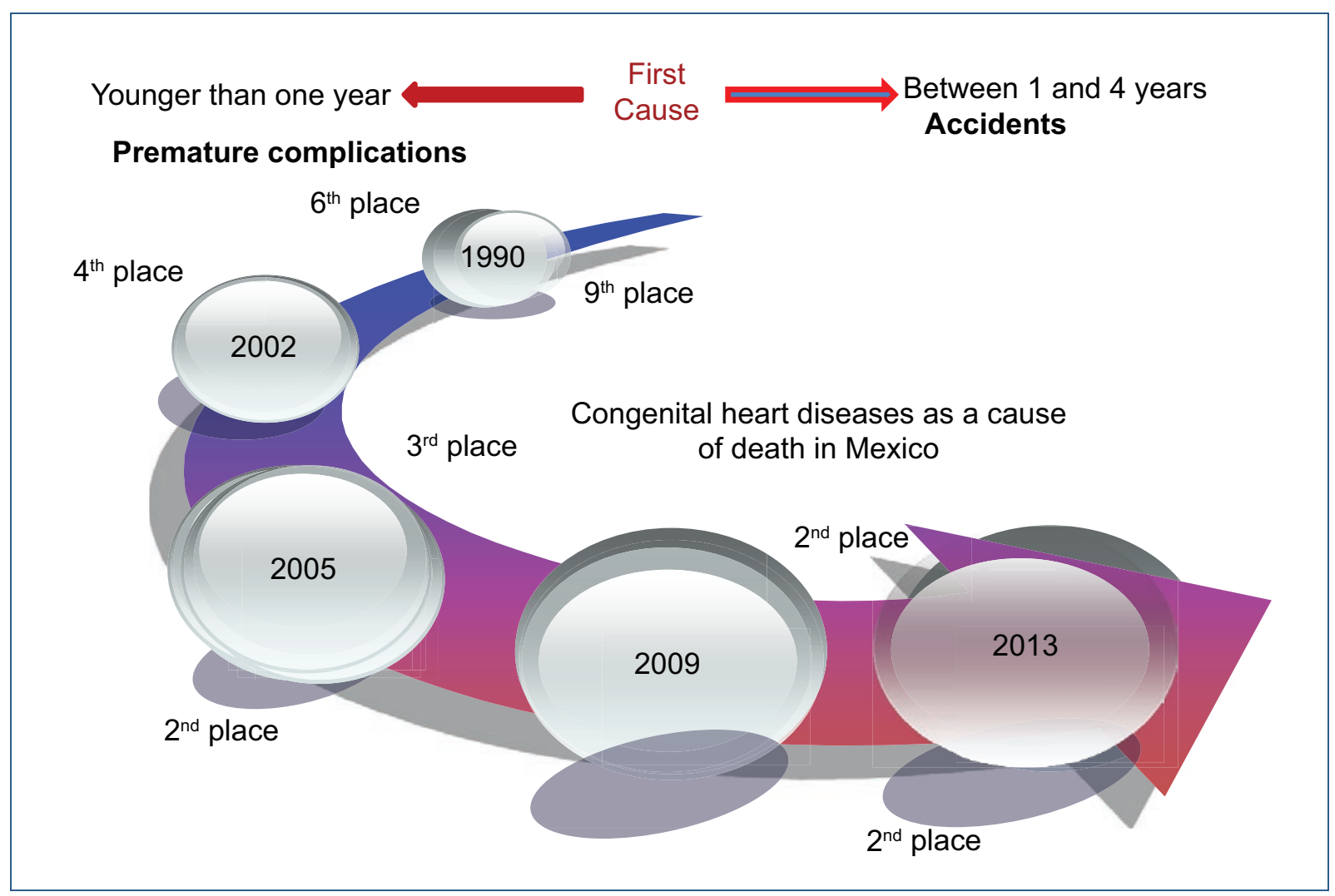

Figure 3. Causes of mortality in Mexico.

thousand children are born with CHD. Another way for establishing its significance is the mortality rate, which in 1990 was at sixth place as a cause of death in children younger than 1 year and since 2005 it became the second cause of mortality, which is the place where it remains until today; in the age group of 1-4 years, it is the second cause of mortality since 2009 (Fig. 3). In the research carried out by Dr. Teresa Murguía-Peniche et al. ${ }^{21}$, children mortality secondary to CHD was found to have increased by $24.8 \%$ throughout the republic from 1988 to 2013, with an increase in the number of deaths from 114.4 to $146.4 / 100$ thousand newborns. In the last year of the study (2013), a total of 3593 CHD-related deaths were documented, with one-third of them occurring during the $1^{\text {st }}$ week of life, and the risk factors that were found were being male, and being born in non-institutional hospitals and rural areas. The authors concluded that CHD is a serious public health problem in our country and that early detection and epidemiological monitoring are required. There is another study, with a similar approach to that of the previous one, where researcher Sánchez-Barriga ${ }^{22}$ analyzed mortality associated with congenital malformations of the heart and great arteries in the 2000-2015 period, and found that 70,741 individuals, among children and adults, died from that cause in the aforementioned period, and the age-adjusted mortality rate per 100,000 rose from 3.3 to 4 ; with regard to those younger than 1 year, the mortality rate per 100,000 live births increased from 143.9 to 217.3 . It should be noted that the region with the highest mortality was socioeconomic region 7 (Mexico City), according to the National Institute of Statistics and Geography (Instituto Nacional de Estadística y Geografía [INEGI]) classification. The researcher claims that the mortality increase can be explained by an improvement in the diagnosis of these pathologies; in my opinion, I consider that the higher mortality that can be observed in Mexico City is a reflection of the high concentration of high-specialty medical services.

The recommendations of the European Association for Cardio-thoracic Surgery (EACTS) CHD Committee establish the need for one hospital with the capacity to perform cardiovascular surgery for every 4 million inhabitants. In 2010, Mexico had a population of 103 million inhabitants and required at least 25 cardiac surgery centers for $\mathrm{CHD}$ adequate care in the country; at that time, there were 11 hospital centers with consistent pediatric cardiac surgery activity, eight of which were based in Mexico City. In 2015, with a population of 119 million inhabitants according to the information provided by INEGI, the number of centers 
with the capacity to perform the necessary pediatric cardiac surgeries should be at least $30^{23}$.

The regionalization proposal considered that the distribution of centers for medical and surgical care of CHD should be based on the following premises: (a) the mortality rate due to malformations of the heart and great arteries in $<1$ year at each one of the states of the country; (b) advantage should be taken of existing hospitals with infrastructure that allows for them to be strengthened with technology and human resources in the short term; (c) emphasis should be given to regions with high birth rate, and (d) areas where transfer of patients is complicated due to both orographic and socioeconomic and cultural factors should be prioritized.

In turn, the Ministry of Health, with the purpose to expand specialized services coverage at the national level for the care of conditions that are infrequent and have high diagnostic and therapeutic complexity, decided to build High Specialty Regional Hospitals (Hospitales Regionales de Alta Especialidad [HRAE]), with the chosen places being: Tuxtla Gutiérrez, Chiapas; Ciudad Victoria, Tamaulipas; Mérida Yucatan; Oaxaca, Oaxaca; Silao, Guanajuato, and Ixtapaluca, State of Mexico. Among them, the only one that lacks a pediatrics department is the Oaxaca HRAE, with the reason for this being unknown, since this state has a population of more than 4 million inhabitants, a high birth rate and marginality with serious socio-economic and cultural problems that make it very difficult for heart disease patients to be transferred to Mexico City for their care. The following can be said with regard to CHD surgery at the different HRAEs: the Ixtapaluca hospital started operating on March 29, 2012, in spite of which, even today, the volume of pediatric patients undergoing cardiac surgery is reduced; it should be borne in mind that the state of Mexico is the most populated in the country, with 16 million inhabitants according to INEGI, which would require, based on EACTS suggestion, for that entity to have four centers capable of carrying out this type of intervention in a number of around 250 surgeries per year; the High-Specialty Regional Hospital of the Bajío region has been operating for 11 years and, although it has the necessary technological and human resources, the number of $\mathrm{CHD}$ corrective and palliative performed surgeries, the degree of complexity and the results in terms of morbidity and mortality are unknown, since it has not participated in the National Registry of Pediatric Cardiac Surgery (Registro Nacional de Cirugía Cardiaca Pediátrica [RENACCAPE]), or in any other national or international information platform. Another situation is faced by the Tuxtla Gutiérrez, Chiapas problems, the number of surgeries that are carried out is minimal, which has been partially compensated with the interventional catheterization approach (ductus arteriosus and atrial septal defect closure, aortic coarctation plasty, and pulmonary stenosis balloon dilation, among others) and surgical workshops carried out by medical and paramedical personnel of some USA hospital centers. In this regard, it should be mentioned that Dr. Aldo Castañeda, an icon in international pediatric cardiovascular surgery, used to disapprove those events, which he referred to as "medical safaris," where a group of doctors and paramedics from developed countries travel to different underdeveloped regions to carry out cardiac surgery in children without leaving any substantive knowledge in local work teams; surgical tourism should be restricted to those countries or regions of countries that hardly will have the capacity to have autonomous cardiothoracic programs ${ }^{22}$. With regard to the Ciudad Victoria HRAE in Tamaulipas, a cardiovascular surgeon with subspecialty in CHD was recently added to the workgroup, and gradual achievement of higher surgical volume is to be expected. Finally, regarding the HRAE based in Mérida, Yucatán, the medical and paramedical groups have already started having commendable results, not without difficulties, in terms of a larger number of surgeries, interventional catheterizations, and complexity of treated cases.

In 2007, the World Society for Pediatric and Congenital Heart Surgery (WSPCHS) was established, with the mission to optimize the care of patients with CHD worldwide. To achieve this objective, the creation of registries with the purpose to know the world situation with regard to the surgical treatment of patients with $\mathrm{CHD}$ was proposed as one of the strategies. In Mexico, the Mexican Association of Specialists in CHDs (Asociación Mexicana de Especialistas en Cardiopatías Congénitas [AMECC]) was created in 2006, which brings together the majority of specialists who are interested in and manage CHDs in our country, as a sister association to WSPCHS. At the WSPCHS World Summit, celebrated in Montreal in 2008, a commitment was made to improve the cardiac care of children with CHD in the world, and AMECC, represented by Dr. Samuel Ramírez Marroquín, endorsed that huge challenge. It is important mentioning that AMECC statutes article 5 establishes that its mission is to organize collective work with the participation of all government and private institutions whose goal is that all patients with a congenital heart defect that reside in the national territory have access to adequate medical and surgical care. Dr. Christo Tchervenkov, former WSPCHS president, summarized his vision of the approach to $\mathrm{CHD}$ care and named it the 
"medicine of respect," whose pillars are: responsibility, education, sustainability, partnership, empowerment, commitment, teamwork, and trust ${ }^{24}$.

With this background, in 2010, a Pediatric Cardiology and Cardiac Surgery collegiate group was formed, as an agency the National Institutes of Health and High Specialty Hospitals Coordinating Commission (Comi-sión Coordinadora de los Institutos Nacionales de Salud y Hospitales de Alta Especialidad [CCINSAHE]), coordinated by Dr. Manuel de la Llata, where several actions were established in the field of CHD: the first one was to carry out the regionalization project for the surgical care of children afflicted with $\mathrm{CHD}$; the second action was to conduct a census of human resources and technology for the care of these patients in the country. The census showed that $67 \%$ of $\mathrm{CHD}$ treatment in Mexico was by means of surgery and the rest by means of interventional catheterization and that $85 \%$ of these procedures were carried out in large hospital centers of Mexico City, Monterrey, and Guadalajara. The total number of cardiovascular surgeries performed in 2009 was 4000, which yields an average of 38 surgeries per million population, while average $\mathrm{CHD}$ surgery per million population in Europe is 62 and in Spain $52^{25}$. The third action was the creation of a database, RENACCAPE, which, using the international nomenclature, would allow obtaining information on the work carried out in different centers of the country and would allow quantifying the progress made. This database was designed and completed with his own resources by Dr. Jorge Cervantes Salazar and was made available, free of charge, to CCINSAHE and AMECC ${ }^{26}$. With the database information, the publication of the first pediatric cardiac surgery report was accomplished, which encompassed from August 1, 2011, to July 31, 2012 , and that had the information of practically 1000 patients included, with the participation of the following institutions, with their respective percentages: Ignacio Chavez National Institute of Cardiology (40\%); Federico Gómez Children's Hospital of Mexico (25\%); National Institute of Pediatrics (16\%); Hidalgo Hospital, in Aguascalientes (12\%); High Specialty Regional Hospital, Tuxtla Gutiérrez, Chiapas (6\%); and High Specialty Regional Hospital in Mérida, Yucatán, and High Specialty Regional Hospital of Oaxaca $(0.4 \%)$. With regard to treated patients, $10 \%$ corresponded to newborns, $29 \%$ to children younger than 1 year $30 \%$ to children aged $1-5$ years. The surgical indication was elective in $89 \%$ and mortality in the entire group was $8 \%{ }^{25}$.

A subsequent publication recapitulated the advances and pending issues in this regionalization process in the WSPCHS journal. This publication deserved an editorial by pediatric cardiologist Sara K. Pasquali, from the
Michigan Medicine Congenital Heart Center, and Jeffrey P. Jacobs, Head of the Cardiovascular Surgery Division of the Johns Hopkins All Children's Heart Institute, where they expressed: "rigorous collection of significant data to inform the best practices has been shown to be a critical first step, and the Mexican Association of CHD Specialists should be commended for taking this important step to improve the quality of care in children with $\mathrm{CHD}$ in Mexico. Future collaborative efforts between RENACCAPE (Mexican database) and the STS CHD surgery database may further facilitate this goal. This expanded database could further improve and support the analysis of results and the improvement of quality in patients with congenital and pediatric heart disease in North America."27,28

In the WSPCHS $4^{\text {th }}$ scientific session, which took place in Sao Paulo, Brazil, in 2014, the need to establish a global database whose purpose would be to promote knowledge about global practice and pediatric and congenital heart surgery results were discussed. The need to have a tool to promote quality improvement without geographical or economic limitations regarding eligibility in participating hospitals and that would be a source of information to assess the progress in providing surgical care to children with CHD in the world was also discussed. This project, the World Database for Pediatric and Congenital Heart Surgery, crystallized in 2017 and, according to the latest report, there are 48 registered hospital centers that have reported 3436 surgeries. In Mexico, health centers participate through the National Institute of Pediatrics and the ABC-Kardias Pediatric Heart Center, the Pediatric Heart Disease Surgical Program and the Ignacio Chavez National Institute of Cardiology ${ }^{29}$.

There is another database, the International Quality Improvement Collaborative for CHD (IQIC), which was initiated officially in 2008 and whose purpose was to obtain information on congenital heart surgery in limited-resource settings, with the general purpose to guide quality improvement efforts and reduce $\mathrm{CHD}$ surgical mortality. At present, there are 64 centers from 25 countries registered in IQIC. Mexico participates through the National Institute of Pediatrics and the Kardias Pediatric Heart Disease Surgical Program A.C. and the ABC Medical Center ${ }^{30}$.

The collegiate group of what was formerly called $\mathrm{CHD}$ Care Regionalization Coordinating Council remained in office until 2017, after having held, apart from the aforementioned, two national meetings with analysis and discussion forums on topics of high importance for the fields of pediatric cardiology and pediatric cardiovascular surgery. Unfortunately, the group was dissolved without having achieved the goals it was created for since the authorities considered other priorities in health policies. 
CHD surgical care in our country has been gradually compensated for in different ways by the effort of Doctors and Civil Societies. Achievements at the Miguel Hidalgo Centennial Hospital in Aguascalientes (12\%), where a pediatric cardiac surgery program is being carried out with a good volume of operated cases, and with increasingly higher degrees of complexity, should be highlighted. A useful tool has been applied in this state: the "partnership program," with the Ignacio Chavez National Institute of Cardiology, which consists in analyzing the most complex cases and, after consensus is reached, deciding on the surgical approach and the institution where the procedure is to be carried out. If required, one of the cardiovascular surgeons of the Ignacio Chavez National Institute of Cardiology, as well as surgeons and anesthesiologists, participate with the local surgical team in Aguascalientes. Interventional catheterizations are also being performed with the valuable support of Dr. José Antonio García Montes. This program is the result of the spirit and enthusiasm of pediatric cardiologists, especially Dr. Julieta González Palacios, and cardiovascular surgeons of that institution and the financial resources that support the program come from the state and Seguro Popular. This program has allowed the vast majority of CHDs of the state to be managed and has had a positive influence in surrounding states such as Zacatecas. A similar program is carried out in other hospitals such as the Sinaloa Pediatric Hospital, which receives support from cardiovascular surgeons from Monterrey or Mexico City whenever it is necessary.

Another experience worth mentioning is that of Mexicali General Hospital in Baja California, where a successful pediatric cardiac surgery program has been accomplished, through surgical workshops, where a specialized team of cardiovascular surgeons from the Ignacio Chavez National Institute of Cardiology participates, as well as local surgeons and anesthesiologists, hemodynamics specialists, and intensivists. They have achieved an excellent volume of cardiac surgeries, which has included neonatal cardiac surgery. This program can be referred to as a hybrid because the financial resources come from the Seguro Popular, state resources and from the Médicos con Corazón Foundation, which is efficiently administered by the Mexicali General Hospital Board of Trustees. The enormous administrative and coordination work carried out by Dr. Hugo Martínez Espinoza deserves to be specially mentioned.

Another hybrid program developed in Mexico City is the one promoted by the Kardias Foundation and the ABC Medical Center, Private Assistance Institution (Institución de Asistencia Privada) and led by cardiovas- resources are provided by the Foundation, the Hospital, and the Seguro Popular. It should be noted that this program is carried out year-round and has strategic support of the Texas Children's Hospital. From being a purely surgical program, since the second half of 2017 it has been complemented with interventional catheterization. Another program with entirely private resources is the one called Invincible Hearts, carried out through surgery or interventional catheterization workshops at the Zambrano Hellion Hospital in Monterrey, with financial support of the TecSalud Foundation and the CardioChavitos Association, with voluntary participation of local medical specialists, health professionals from the San José and Zambrano Hellion hospitals and doctors from the International Children's Heart Foundation. In addition, at los Cabos $\mathrm{H}_{+}$, the Corazon de Niño Foundation carries out workshops called Unidos de Corazón addressing interventional catheterizations, therapeutic electrophysiological studies and pediatric cardiac surgeries with resources donated by the civil society and with the support of said hospital. Specialist doctors from different states of the republic participate in these medical events and, in parallel, CHD diagnostic sessions are held.

It is necessary to delve into the so-called "brotherhood" programs where a partnership of two cardiac programs is established: one, an established center of excellence, and the other, some evolving program in a developing country, to establish a value relationship for both Institutions. In those countries where one of the main problems is poor access to medical care, existing centers of excellence can contribute to the creation and support of new centers, which might be called national brotherhood or mentoring programs. International partnership programs are essential in countries without centers able to provide such support. The following points are essential to achieve success in this association: (a) aiming to work as a team, with this including sharing responsibility and establishing an open information exchange; efforts should focus on education and sustainability of the program; (b) establishing the need to measure the results of their cardiothoracic departments to improve the program, and for this, there should be a reliable database available, whose results should be periodically reviewed by the institution with the clear goals of increasing surgical volume, improving quality, and reducing morbidity and mortality; (c) ideally, having a fundraising structure, be it civil society organizations or local foundations, with a transparent management of funds that allow adequate channeling and use of resources, and (d) building bridges to obtain government and local community support for sustainability of the program with established objectives in the medium and long term ${ }^{31}$. 


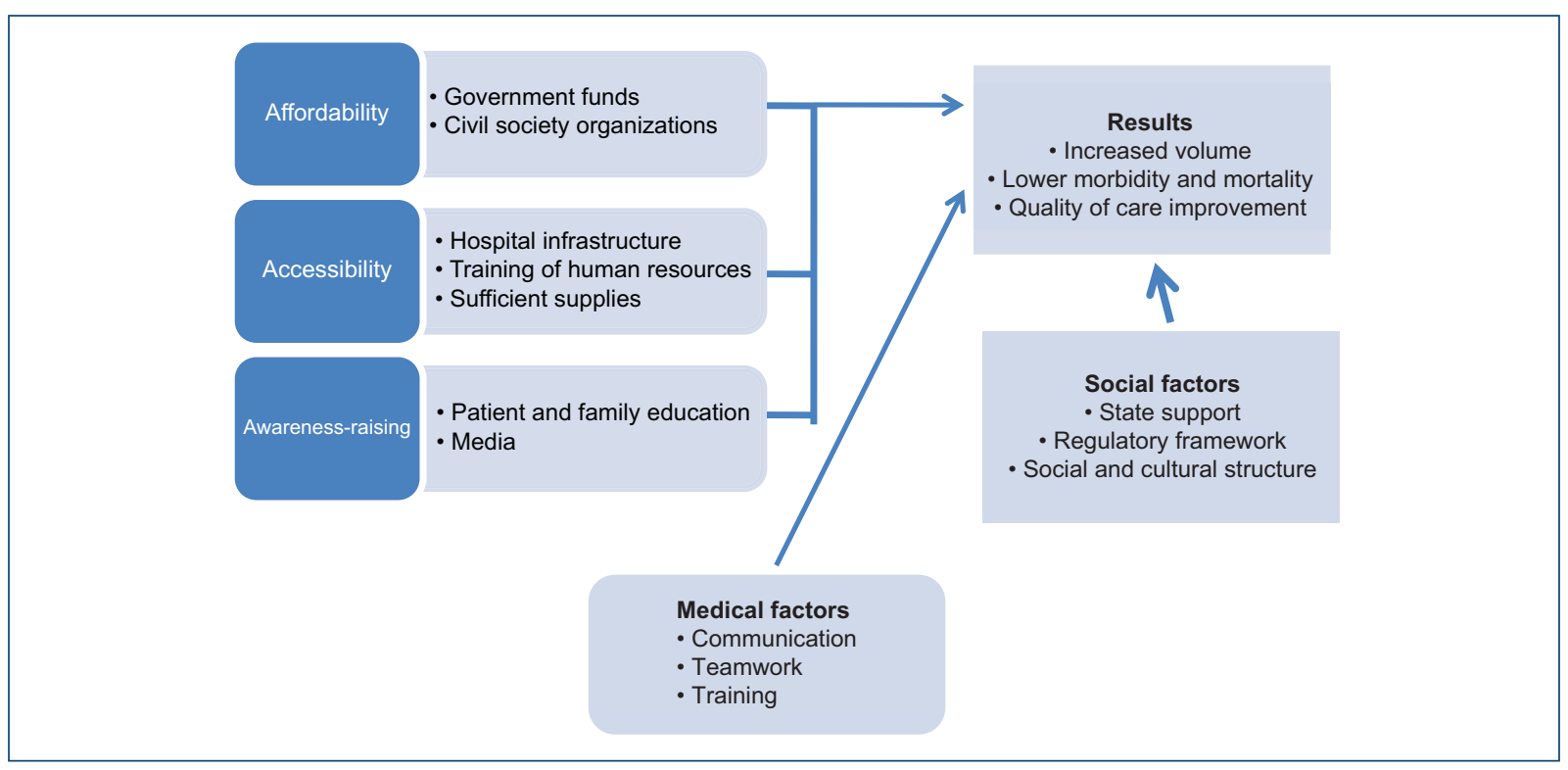

Figure 4. Priorities in the care of congenital heart diseases (adapted from Dearani et al., 2016). ${ }^{31}$

There are other associations aimed at the care of deprived children who suffer from a heart condition and who require corrective heart surgery or interventional catheterization, such as the Children's Rights Foundation, created by engineer Luis Martínez Zepeda (19152010), who studied at the National Polytechnic Institute and had a remarkably deep social vision. This foundation has decidedly supported the care of children with heart conditions with important resources in several hospitals: National Institute of Cardiology, Children's Hospital of Mexico, National Institute of Pediatrics, and Tuxtla Gutiérrez Pediatric Specialties' Hospital. The Aid for Children in Critical Conditions Association (Asociación de Ayuda de Niños en Estado Crítico [ADANEC]), with more than two decades of existence, has done a laudable work in the surgical care of children afflicted with some type of CHD. This association carries out surgical workshops in different parts of the country, with those interventions of higher complexity carried out at the Maternal and Child Health High-Specialty Hospital in Monterrey by the ADANEC health team. In this account, it is important mentioning the Gonzalo Río Arronte Foundation, which has wide recognition in the health sector for its contribution to technological modernization and to medical services coverage broadening in our country. It grants in-kind donations to institutions, hospitals, clinics, and health centers that provide health services to people with limited resources or in situations of vulnerability.

With the above-described examples, it is clear that the civil society has decidedly supported the care of children with congenital heart pathologies and that this work has been of great relevance, but the goal of providing care to all children with $\mathrm{CHD}$ in a timely manner and with quality cannot be achieved despite the valuable efforts of all these organizations that work in an admirable form but in an isolated form. As Dearani et al. ${ }^{32}$ well express it, the purpose to improve access to care for children with CHD can only be achieved by building group alliances and coordinating their efforts. It is necessary to promote cooperation, not competition, since this causes unnecessary effort duplication and ends up being inefficient. It would be desirable to establish bridges between different civil organizations and health institutions to exchange ideas that allow the creation of consensuses and joint projects for better use of available resources.

To round off, it can be concluded that, in the field of health policy, the Ministry of Health should consider the care of CHDs as a national priority for greater financial resources to be allocated, with a highly efficient administrative management to build sufficient hospital infrastructure, as well as strengthening and consolidating, in a strategic way, the already existing different working groups at regional hospitals, with support to the National Institutes of Health having to be increased for them to continue as knowledge-generating centers and sites for the training of specialized human resources and centers that accompany different pediatric cardiac surgery and interventional catheterization programs in the country. Accessibility, availability, and affordability of surgical or interventional catheterization care for CHD should be achieved $^{33}$. The goals in the assistance sphere are: (a) achieving the care of children afflicted with $\mathrm{CHD}$ 
throughout the country; (b) consolidating work teams at High Specialty Regional Hospitals (HRAEs); (c) strengthening State Hospitals with the capacity to perform pediatric cardiac surgery; (d) using the national RENACCAPE database to have a tool that allows knowing the work carried out in this field in the country and that allows to assess the advances, and (e) obtaining adequate results in comparison with international standards. From a societal point of view, the look of society must be directed towards the importance of CHD in our country (Fig. 4).

It is necessary to reflect on the challenges that we must face and remember what Sir George Alleyne, Peace Science Award of the Inter-American Foundation of the Heart (2008) and Doctor Honoris Causa by the University of Toronto (2017), rightly stated ${ }^{6}$ : "health equity is fundamentally an ethical-moral issue and we should not refuse to consider it this way."

\section{Funding}

The present investigation has not received specific aid from public or commercial sector agencies or non-profit entities.

\section{Conflicts of interest}

The author declares that they have no conflicts of interest.

\section{Ethical disclosures}

Protection of people and animals. The author declares that no experiments have been carried out on humans or animals for this investigation.

Confidentiality of data. The author declares that no patient data appear in this article.

Right to privacy and informed consent. The author declares that no patient data appear in this article.

\section{References}

1. Knaul FM, Arreola-Ornelas $\mathrm{H}$, Méndez-Carniado O. Protección financiera en salud: actualizaciones para México a 2014. Salud Pública Mex. 2016;58:341-50.

2. Health spending. Related topics [Internet]. Organisation for Economic Co-operation and Development; 2018. Disponible en: https://data.oecd. org/healthres/health-spending.htm.

3. Global Health Expenditure Database. World Health Organization Expenditure database [Internet]. Ginebra: World Health Organization [fecha de última actualización: 4 de abril de 2019]. Disponible en: http://apps.who. int/nha/database.

4. Frenk J, Knaul FM, Gómez Dantes O, Arreola Ornelas H. La brecha de la salud. Nexos. 2018;40(482):20-5.

5. Cano Valle F, Pantoja Nieves M, Sánchez Miguel M. El Péndulo de Medicina. El doble péndulo de la salud. Urge una reforma en el sistema de salud. México: Editorial Prado, Instituto de Investigaciones Jurídicas; 2017.

6. Cano Valle F, coord. La Salud universal... una entelequia. La posición de la Academia ante el Sistema NAcional de Salud. México: Academia Nacional de Medicina; 2018. pp. 15-28.
7. Organization for Economic Co-operation and Development. (OECD) (Internet). Reviews of Health Care Systems: Mexico 2016. Disponible en: https://www.oecd.org/health/health-systems/OECD-Reviews-of- Health-Systems-Mexico-2016-Assessment-and-recommendations-Spanish.pdf.

8. Cutler D. Buried in healthcare imbroglio, trillion-dolar question [Internet]. The Harvard Gazzete; 2017. Disponible en: https://news.harvard.edu/gazette/ story/2017/08/looking-beyond-d-c-debate-harvard-economist-zeroes-in-on-cost/

9. Bloom DE, Canning D, Sevilla J. The effect of health on economic growth: a production function approach. World Development. 2004;32(1):1-13.

10. Frenk J, González-Pier E, Gómez-Dantes O, Lezana MA, Knaul FM. Comprehensive reform to improve health system performance in Mexico. Lancet. 2006;368:1524-134.

11. Ávila-Burgos L, Serván-Mori E, Wirtz VJ, Sosa-Rubí S, Salinas-Rodríguez A. Efectos del Seguro Popular sobre el gasto en salud en hogares mexicanos a diez años de su implementación. Salud Publica Mex. 2013:55(suppl 2):S91-9.

12. Knaul FM, Arreola-Ornelas H, Méndez-Carniado O, Bryson-Cahn C, Barofsky J, Maguire R, et al. Evidence is good for your health system: policy reform to remedy catastrophic and impoverishing. Lancet. 2006:368:1828-41.

13. Organization for Economic Co-operation and Development (OECD) (Internet). MEXICO Country Highlights OECD, Doing Better for Children. Disponible en: https://www.oecd.org/mexico/43590178.pdf

14. Información obtenida de Indicadores Mundiales - IndexMundi. Disponible en: https://www.indexmundi.com/g/g.aspx?c=mx\&v=29\&l=es

15. Calderón-Colmenero J, Ramírez-Marroquín S, Cervantes-Salazar J. Métodos de estratificación de riesgo en la cirugía de cardiopatías congénitas. Arch Cardiol Méx. 2008;78:60-7.

16. O'Brien SM, Clarke DR, Jacobs JP, Jacobs ML, Lacour-Gayet FG, Pizarro C, et al. An empirically based tool for analyzing mortality associated with congenital heart surgery. J Thorac Cardiovasc Surg. 2009;138(5):1139-53.

17. Calderón-Colmenero J, Cervantes-Salazar JL, Curi-Curi JP, Ramírez-Marroquín S. Problemática de las cardiopatías congénitas en México. Propuesta de regionalización. Arch Cardiol Mex. 2010;80(2):133-40.

18. Mitchell SC, Korones SB, Berrendees HW. Congenital heart disease in 56,109 births. Incident and natural history. Circulation. 1971;43:323-32.

19. Fyler DC. Report of the New England regional infant cardiac program Pediatrics. 1980;65(suppl):S376-S61.

20. Hoffman JIE, Kaplan S. The incidence of congenital heart disease. J Am Coll Cardiol. 2002;39:1890-9.

21. Torres-Cosme JL, Rolón-Porras C, Aguinaga-Ríos M, Acosta-Granados PM, Reyes-Muñoz E, Murguía-Peniche T. Mortality from congenital heart disease in Mexico: A problem on the rise. PLoS One. 2016;11(3):e0150422.

22. Sánchez-Barriga JJ. Mortality trends from congenital malformations of the heart and great vessels in children and adults in the seven socioeconomic regions of México, 2000-2015. Congenit Heart Dis. 2018;13(5):690-9.

23. Daenen W, Lacourt-Gayet $F$, Aberg T. Optimal structure of a congenital heart surgery department in Europe by EACTS congenital heart disease committee. Eur J Cardiothorac Surg. 2003;24:334-51.

24. Jacobs JP, Tchervenkov $\mathrm{Cl}$, Stellini G, Kurosawa $\mathrm{H}$, Mavroudis $\mathrm{C}$, Jatene MB, et al. Historial of the World Society for Pediatric and Congenital Heart surgery: the first decade. World J Pediatr Congenit Heart Surgery. 2018;9(4):392-06.

25. Calderón-Colmenero J, De la Llata M, Vizcaíno A, Ramírez S. Atención médico-quirúrgica de las cardiopatías congénitas: una visión panorámica de la realidad en México. Encuesta 2009. Rev Invest Clin. 2011; 63(4):344-52.

26. Cervantes-Salazar J, Calderón-Colmenero J, Ramírez-Marroquín, Palacios-Macedo A, Bolio-Cerdán A, Vizcaíno A, et al. Registro Mexicano de Cirugía Cardiaca Pediátrica. Primer Informe. Rev Invest Clin. 2013; 65(6):476-82.

27. Calderón-Colmenero J, Cervantes-Salazar J, Curi-Curi P, Ramírez-Marroquín S. Congenital heart disease in Mexico: Advances of the Regionalization Project. World J Pediatr Congenit Heart Surg. 2013;4(2):165-71

28. Pasquali SK, Jacobs JO. The role of databases in improving the quality of care for congenital heart disease. World $\mathrm{J}$ Pediatr Congenit Heart Surg. 2013:4(2):139-41.

29. St. Louis JD, Kurosawa H, Jonas RA, Sandoval N, Cervantes J, Tchervenkov $\mathrm{Cl}$, et al. The World database for pediatric heart surgery. The Dawn of a new era of global communication and quality improvement in congenital heart disease. World J Pediatr Congenit Heart Surgery. 2017;8(5):597-99.

30. International Quality Improvement Collaborative [Internet]. Minneapolis, MN Children's HeartLink; 2018. Disponible en: https://childrensheartlink.org/iqic/

31. Dearani JA, Jacobs JP, Bolman M, Swain JD, Vricella LA, Weinstein S, et al. Humanitarian outreach in cardiothoracic surgery: From setup to sustainability. Ann Thorac Surg. 2016:102:1004-11.

32. Dearani JA, Neirotti R, Kohnke EJ, Sinha KK, Cabalka AK, Barnes RD, et al. Improving pediatric cardiac surgical care in developing countries: Matching resources to needs. Semin Thorac Cardiovasc Surg Pediatr Card Surg Ann. 2010;13:35-43.

33. Saxton AT, Poenaru D, Ozgediz D, Ameh EA, Farner D, Smith ER, et al. Economic analysis of children's surgical care in low- and middle-income countries: A systematic review and analysis. PLoS ONE. 2016;11(10):1-20. 